\title{
4: $188020126-187884098$
}

National Cancer Institute

\section{Source}

National Cancer Institute. 4:188020126-187884098. NCI Thesaurus. Code C42249.

Physical location of FAT_Gene 